\title{
RESEARCH OF SOCIO-EMOTIONAL COMPETENCE AND ITS IMPORTANCE IN STUDENTS' PERSONALITY DEVELOPMENT
}

УдК 159.942

DOI https://doi.org/10.32843/2663-

5208.2020.18.2.3

\section{Бойченко А.О.}

аспірантка

Українська інженерно-педагогічна академія,

молодший науковий співробітник ДУ «Інститут охорони здоров'я дітей та підлітків Національної академії медичних наук України»

\section{Шукалова О.С.}

к.психол.н., доцент,

доцент кафредри педагогіки, психології, початкової освіти та освітнього менеджменту

К3 «Харківська гуманітарно-педагогічна академія» Харківської обласної ради

\section{Джаббарова л.в.}

викладач психології кафедри

педагогіки, психології, початкової освіти та освітнього менеджменту

КЗ «Харківська гуманітарно-педагогічна академія» Харківської обласної ради у статті здійснено теоретико-аналітичний огляд наукових розвідок учених на предмет пошуку конгруентного психосоціального конструкту молодої людини, що відповідає сучасним мінливим викликам суспільства.

Розглянуто поняття «соціальний інтелект» та «емоційний інтелект», установлено зв'язок між ними, заснований на схожості структур, що дає змогу інтегрувати ї у поняття «соціоемоційний інтелект». Відсутність у структурі соціоемоційного інтелекту регуляційного, поведінкового компонента зумовило подальші пошуки. Проаналізовано поняття «соціальна компетентність» та «емоційна компетентність», знайдено їх специфрічні точки перетину. Єднальними категоріями для означених конструктів є поняття «спілкування», «пізнання», «розуміння» й «діяльність», які дають змогу об'єднати їх у єдине поняття «соціоемоційна компетентність». Проведено дослідження сутності соціально-емочійної компетентності, ї̈ визначень, структурних компонентів, найбільш стабільними з яких виявилися такі: розуміння емоцій чужих і власних, саморегуляція та емпатія. Установлено, що соціально-емоційна компетентність є саме тим особистісним конструктом, формування й розвиток якого сприяє порозумінню особистості не тільки із соціальним середовищем, а й із власним «Я»; визначено їі провідну роль саме для студентської молоді як специфрічної вікової категорії, що потребує додаткових внутрішніх резервів.

Узагальнені сорери життєдіяльності студентства, для яких високий рівень розвитку соціоемоційної компетентності є особливо актуальним, а саме особистісну, міжособистісну та навчально-професійну сфери. Висунуто припущення, що високий рівень означеної компетентності може позитивно позначатися на саморегуляції, життєстійкості, емоційній стабільності студентів, оптимізувати їхню стрес-долаючу поведінку, розвивати оптимізм, орієнтувати локус контролю на інтернальний, підвищувати самооцінку й упевненість у собі. Установлено, що соціоемоційна компетентність може бути дієвим предиктором численних психологічних ускладнень, характерних для студентського періоду життя

Ключові слова: соціальний інтелект, емоційний інтелект, соціоемоційний інтелект, соціальна компетентність, емоційна компетентність, соціоемоційна компетентність, саморегуляція, студентський вік.

The article provides a theoretical and analytical review of scientific research to find a congruent psycho-social construct of young people that meets the current changing challenges in society. The concepts of "social intelligence" and "emotional intelligence" are considered, the connection between them is established, based on the similarity of structures, which allows to integrate them into the concept of "socioemotional intelligence". The absence of a regulatory, behavioral component in the structure of socio-emotional intelligence led to further research. The concepts of "social competence" and "emotional competence" are analyzed, their specific points of intersection are found. The unifying categories for these constructs are the concepts of "communication", "cognition", "understanding" and "activity", which allow us to combine them into a single concept of "socioemotional competence".

A study of the essence of socio-emotional competence, it's definitions, structural components, the most stable of which were the following: understanding the emotions of others and their own, self-regulation and empathy. It is established that socio-emotional competence is precisely the personal construct, the formation and development of which contributes to the understanding of the individual not only with the social environment, but also his own "l"; it's leading role for student youth as a specific age category that needs additional internal reserves has been identified.

Generalized spheres of student life, for which a high level of development of socio-emotional competence is especially relevant, namely personal, interpersonal and educationalprofessional spheres. It is assumed that a high level of this competence can have a positive effect on self-regulation, vitality, emotional stability of students, optimize their stress-relieving behavior, develop optimism, focus the locus of control on the internal, increase self-esteem and self-confidence. It is established that socio-emotional competence can be an effective predictor of numerous psychological complications characteristic of the student period of life.

Key words: social intelligence, emotional intelligence, socio-emotional intelligence, competence, social competence, emotional competence, socio-emotional competence, student age.
Постановка проблеми. В умовах поступального розвитку людської цивілізації, інтернаціоналізації, глобалізації та орієнтації на демократизацію соціальних відносин підвищуються вимоги до образу сучасної молодої людини, яка повинна вміти орієнтуватися в мінливому соціокультурному просторі, вести соціальний діалог і вибудовувати конструктивні взаємини.

Необхідністьформуватий розвиватив молодої людини спеціальні внутрішні резерви, відповідні суспільним запитам, підкреслює актуальність дослідження. Означений ресурс, на 
нашу думку, має охоплювати такі компоненти: здатність до взаєморозуміння, взаємопізнання й рефлексії; спроможність до саморегуляції, емоційної виразності й емпатії; високі рівні соціальної активності, соціальної автономності та соціальної адаптивності. За умови опанування комплексом перелічених здатностей особистість зможе перебувати в гармонії із соціальним оточенням і власним «я».

Аналіз останніх досліджень і публікацій. Дослідження вищеозначених здатностей є темою наукових праць багатьох учених (К. Веар, Д. Големан, Дж. Дансмор, С. Денхем, Е. Ізотова, Дж. Майер, Е. Нікіфорова, Ф. Понс, М. Росней, К. Саарні, П. Саловей, К. Тарасова, Т. Усиніна, А. Халберштадт, П. Харріс та інші).

Постановка завдання. Метою статті $€$ теоретико-аналітичне обґрунтування соціоемоційної компетентності та ї̈̈ значення в розвитку особистості студентів.

Виклад основного матеріалу дослідження. Проведемо теоретичний огляд наукових розвідок на предмет пошуку психосоціального конструкту, що відповідатиме нагальним соціальним викликам. Вивчаючи вказану проблематику, варто розглянути соціальний та емоційний інтелект як базові системи психосоціальної сфери.

Поняття соціального інтелекту (далі - Cl) увів у психологічну науку в 1920 р. Е. Торндайк. Трохи згодом Ф. Вернон запропонував своє визначення соціального інтелекту, розуміючи його як здатність людини вживатися з іншими, соціальну природність у суспільстві, знання соціальних значень, сприйнятливість до стимулів від інших членів групи, а також розуміння тимчасових настроїв або основних рис індивідуальності незнайомців [13].

Розробляючи методику для вимірювання Cl, Дж. Гілфорд виокремлює його складники, засновані на пізнанні елементів поведінки; класів поведінки; відносин поведінки; систем поведінки; перетворень поведінки; результатів поведінки [6].

Перейдемододослідження емоційногоінтелекту (далі - El), який першими сформулювали й увели в науковий обіг П. Саловей і Дж. Майер у 1990 р. Дослідники дають таке тлумачення цього терміна: «... здатність сприйняти емоцію, викликати емоцію для полегшення пізнання, розуміти емоції, а також керувати емоціями, щоб сприяти особистісному розвитку». Модель ЕІ вчених включає такі компоненти, як емоційна перцепція; емоційна інтеграція; розуміння емоцій; управління емоціями [11].

3 розвитку $\mathrm{Cl}$ та далі ЕІ як наукових категорій у численних наукових розвідках установлено точки перетину двох систем. Так, у контексті $\mathrm{Cl}$ перераховуються компоненти El: здатність розуміти емоції, почуття, настрої оточення; можливості пізнання своїх емоцій- них станів і саморегуляція; емпатія, прийняття точки зору іншого; можливості пізнання своїх емоційних станів і саморегуляція. Окремо відзначають значення емоційного інтелекту для ситуацій соціальної взаємодії.

Підсумовуючи отриманні дані, В. Семенов робить висновок про нерозривний зв'язок між компонентами Сl й Еl, які містять єдині аспекти розуміння, контролю емоцій і почуттів у себе й оточення. На думку автора, якщо роботи по Cl спрямовані на пізнання поведінки, управління нею, а роботи по Еl присвячені пізнанню й управління емоціями, то безсумнівним $€$ те, що пізнання емоцій неможливо поза пізнання поведінки, адже будь-які емоційні прояви неминуче проявляються в поведінці й відбиваються на ній.

Базуючись на схожості структур El та Cl, науковець уважає, що ці конструкти утворюють єдину здатність - соціоемоційний інтелект (далі - CEI) [7, с. 32].

За В. Семеновим, CEI - здатність індивіда розуміти когнітивні, емоційні, мотиваційні, інтенціональні аспекти своєї поведінки й поведінки інших індивідів у процесі актуальної взаємодії з ними, використовувати суб'єктивні знання про ці аспекти для вибору ефективних стратегій розв'язання соціальних проблем.

Автором запропонована власна структурна модель CEI, що включає такі змінні: прогнозування поведінки, розуміння міміки й жестів, розуміння вербальнихпроявів поведінки, розуміння інтенцій і потреб учасників комунікації, розпізнавання причинно-наслідкових зв'язків у міжособистісних ситуаціях, соціальні знання, розуміння емоційних станів оточення, управління чужими емоційними станами, розуміння своїх емоційних станів, управління своїми емоційними станами, контроль своїх невербальних проявів, соціальне усвідомлення (чутливість), соціальні навички [7, с. 78-79].

Можна стверджувати, що CEI охоплює більшість компонентів, які необхідні особистості для забезпечення гармонійного внутрішнього стану та продуктивної міжособистісної комунікації. Однак, аналізуючи складники структури означеного конструкту, можемо констатувати, що безсумнівним є брак регулятивного, поведінкового компонента. Уважаємо необхідним продовжити теоретичне дослідження в напрямі пошуку більш конгруентного конструкту.

Зважаючи на системний, інтегративний характер необхідного ресурсу, уважаємо за доцільне характеризувати його як компетенцію.

Компетенція розуміється як ознака або якість особистості, потенційна здатність вирішувати різноманітні завдання; як сукупність взаємопов'язаних знань, умінь, навичок і способів діяльності, необхідних для якісного та продуктивного функціонування, заданих 
стосовно означеного кола предметів і процесів. Поряд із цим компетентність $є$ характеристикою особистісних якостей людини, що володіє відповідною компетенцією [2, с. 25].

Виокремлюють навчальні, загальні, професійні, спеціальні, інформаційні, комунікативні, соціальні та інші компетенції. Зупинимося на соціальній компетентності, як близької до поняття «соціальний інтелект».

В. Куніцина вважає, що соціальну компетентність (далі - СК) необхідно розглядати як систему знань про себе й соціальну дійсність, системусоціальнихуміньінавичоквзаємодії, що дають змогу швидко адаптуватися, приймати рішення. На думкуавтора, соціальна компетентність об'єднує комунікативну, вербальну соціально-психологічну компетентності, его-компетентність і власне соціальну активність [4].

Закордонні дослідники вважають, що CK - це «здатність вибирати й досягати бажаних цілей шляхом набуття контролю над емоціями та поведінкою через установку контактів, вплив на оточення». Учені виділяють ключові поняття, що мають безпосередньо стосуються CK, a саме: контроль (здатності приймати рішення, здійснювати цілепокладання), співробітництво (побудова взаємин) і соціальна активність (здатність адаптувати власні реакцій до вимог ситуації) [10].

3 огляду на те що однозначного визначення СК немає, виділяють завдання, які вирішуються 3 використанням цього конструкту, серед них такі: здатність продуктивно вирішувати проблемні ситуації; ефективність у повсякденній взаємодії з оточенням; уміння досягати поставлених соціальних цілей; здатність брати участь у складних міжособистісних взаємодіях [9, с. 17].

За логікою дослідження, перейдемо до розгляду емоційної компетентності, яка пов'язана з El й заснована на ньому. Наявність El $є$ необхідною умовою для формування конкретних компетенцій, пов'язаних з емоціями.

Емоційна компетентність (далі - ЕК) виражається в здатності вибудовувати й підтримувати взаємини з іншими людьми, контролювати свою поведінку й емоційні реакції, адекватно сприймати й розуміти партнера по взаємодії, бути більш успішним у соціальних контактах [3].

Поряд із цим ЕК розглядають як здатність особистості до здійснення координації між емоціями та поведінкою, конструкт, що поєднує емоції, інтелект і волю, розвиненість яких зумовлює успішність адаптації до соціального оточення й життєвих ситуацій [5].

Попри відмінності у визначеннях ЕК, закордонні автори сходяться на тому, що це «здатність до сприйняття, усвідомлення та корекції свого емоційного стану й емоційних станів інших». У структурі ЕК виділяють розуміння своїх і чужих емоцій, правильну їх оцінку, контроль своїх емоцій і конструктивне їх вираження [9, с. 21].

При вивченні СК, яка визначає успішність соціальної взаємодії та соціальну адаптацію, та ЕК, що вказує на рівень успішності діяльності й емоційну зрілість, постає питання про їх перетин.

Так, дослідники в структурі ЕК виділяють низку здібностей соціальної спрямованості: усвідомлення соціальних взаємодій, соціальні навички, здатність до розпізнавання емоцій у міжособистісному контексті. Водночас у структурі соціальної компетентності виділяють низку здібностей емоційної спрямованості: емпатію, здатність до саморегуляції, емоційну виразність. Неспростовним $є$ те, що ефективна міжособистісна взаємодія залежить від сукупності здібностей, пов'язаних з умінням орієнтуватися в соціальних ситуаціях, розпізнавати свої й чужі емоції та керувати ними, вибирати адекватні способи спілкування [9, с. 22].

І. Андрєєва емпірично довела наявність позитивного зв'язку між структурними компонентами соціальної компетентності, представленими комунікативними здібностями, навичками міжособистісної взаємодії й основними складниками емоційної компетентності, такими як емпатія, самоконтроль, уміння вербалізувати, розпізнавати власні емоції й емоції інших людей [1].

Можна стверджувати, що поділ емоційної компетентності та соціальної компетентності $€$ непродуктивним, адже основні функції цих компетентностей зводяться до забезпечення ефективної міжособистісної взаємодії, реалізуються в спілкуванні. Єднальними категоріями СК та ЕК є поняття «спілкування», «пізнання», «розуміння» й «діяльність» [9, с. 23].

Логічною, на нашу думку, є інтеграція конструктів «соціальна компетентність» та «емоційна компетентність» у єдиний психосоціальний конструкт «соціоемоційна компетентність» (далі - CEK).

За визначенням К. Веар, «соціоемоційна компетентність - це цінності, знання, уміння сприймати, оцінювати й виражати емоції; генерувати і звертатися до почуттів; розуміти емоції; здатність регулювати емоції для забезпечення емоційного та інтелектуального зростання» [14].

Дослідниця К. Саарні визначає СЕК яК уміння виражати емоції відповідно до цілей і соціальної ситуації, розрізняти й розпізнавати емоції інших людей, включаючи складні та змішані емоції. Відповідно до її точки зору, у розвитку СЕК важливу роль відіграє обробка інформації: декодування соціальних сигналів, генерація стратегій розв'язання проблеми й оцінювання їх ефективності [12]. 
На противагу зарубіжним науковцям, учена Т. Усиніна дійшла розуміння CEK як інтегральної здатності, що забезпечує ефективну міжособистісну взаємодію. На думку дослідниці, структура СЕК охоплює сукупність когнітивного (взаєморозуміння, взаємопізнання, рефлексія), емоційного (саморегуляція, емоційна виразність, емпатія) і поведінкового (соціальна активність, соціальна адаптивність ісоціальна автономність) компонентів [9, с. 32] .

Ми вважаємо недоцільним послуговуватися структурою СЕК одного автора. 3 метою більш повного розуміння конструкту варто вивчити моделі інших науковців.

Так, К. Тарасова провела структурний аналіз компонентів СЕК різних учених. Дані їі дослідження можна представити таким чином:

1. А. Халберштадт, С. Денхам і Дж. Дансмор: відправлення емоційного повідомлення, отримання емоційного повідомлення, «відчуття» емоцій.

2. Д. Големан: саморегуляція, розуміння себе, комунікативна мотивація та цілепокладання, емпатія, соціальні навички.

3. К. Саарні: розуміння емоцій, здатність до емпатії, розуміння можливої неконгруетності зовнішнього вигляду та внутрішнього стану, саморегуляція, мотивація спілкування.

4. Дж. Майер, П. Саловей: демонстрація власних емоцій, розрізнення й аналіз емоцій інших, регуляція емоцій, підвищення ефективності мислення за допомогою емоцій.

5. О. Ізотова, О. Нікіфорова: уявлення про емоції, сприйняття емоційного стану та ідентифікація емоцій, відтворення й кодування емоцій, емоційна регуляція.

6. К. Веар: розуміння себе, розуміння й опанування емоціями, розуміння соціальної ситуації та побудова взаємовідносин.

7. Ф. Понс, П. Харріс, М. Росней: розпізнання, зовнішні причини, бажання, віра, нагадування, регуляція, приховування, змішанні почуття, моральність [8, с. 23-27].

Узагальнюючи основні положення описаних концепцій, відзначимо, що поряд із приватними та специфічними для окремих авторів визначеннями простежуються найбільш стабільні компоненти СЕК, що виділяються більшістю дослідників. До них належать розуміння емоцій чужих і власних як здатність розпізнати емоційні стани й визначити причини їх виникнення; саморегуляція як здатність проявляти свої емоції соціально прийнятними способами; емпатія як здатність до співпереживання й бажання позитивно вплинути на емоційний стан партнера по спілкуванню.

Ми вважаємо, що СЕК є саме тим конструктом, формування та розвиток якого сприяє порозумінню особистості із соціальним середовищем і власним «Я». Особливого значення СЕК набуває серед студентської молоді, яка проходить суперечливий і мінливий етап дорослішання, що потребує додаткових внутрішніх сил.

Студентський вік створює необхідні передумови для успішного розвитку СЕК, що зумовлені появою характерних новоутворень, a саме: становлення нового рівня розвитку свідомості й самосвідомості; визначення життєвих планів; поява свідомого сенсу життя; зародження самопізнання (уявлення про власну індивідуальність, становлення самооцінки, самоповаги); виникнення рефлексії; побудова «Я-концепції», завершення формування ідентичності.

Варто зазначити, що розвиток CEK $€$ актуальним для студентства ще і як чинник, що здатен позитивно позначитися на рівні їх саморегуляції. Розуміючи саморегуляцію як динамічну систему, функціонування якої спрямоване на досягнення самостійності, ініціативності й відповідальності за свої вчинки, ми не можемо ігнорувати надзвичайно вагоме значення цих характеристик для студентського періоду життя.

Уважаємо, що розвинена СЕК позитивно впливає на різні сфери життєдіяльності студентської молоді. 3 метою унаочнення виділимо кожну сферу та відповідні їй здатності окремо:

1. Особистісна: приймати зважені рішення; адекватно і критично оцінювати численні фактори ризику в ситуаціях, специфічних для віку; ефективно адаптуватися до мінливого соціокультурного простору; розуміти свій емоційний стан, його детермінанти, усвідомлювати хід своїх думок.

2. Міжособистісна: успішно взаємодіяти зі своїм соціальним оточенням; вибудовувати контакти з партнерами по взаємодії на емпатійному рівні; правильно розуміти інших, інтерпретувати чужі емоції, розуміти мотиви поведінки соціального оточення; запобігати конфліктним ситуаціям та ефективно вирішувати конфліктні ситуації.

3. Навчально-професійна: продуктивно навчатися в умовах ЗВО; розвивати професійно важливі якості; налагоджувати професійне спілкування в різноманітних навчальних і професійних ситуаціях; успішно здійснювати подальшу професійну діяльність.

Окремо варто зазначити, що високий рівень CEK може позитивно позначатися на саморегуляції, життєстійкості, емоційній стабільності студентів, оптимізувати їхстрес-долаючуповедінку, розвивати оптимізм, орієнтувати локус контролю на інтернальний, підвищувати самооцінку та впевненість у собі. Усе це є предиктором цілої низки ускладнень психологічного характеру, що актуалізуються серед студентів. До таких психологічних проблем зараховуємо підвищений рівень тривожності, синдром емо- 
ційного вигорання, агресивність, ворожість, нервозність, пасивність, негативізм тощо.

Висновки 3 проведеного дослідження. Отже, установлено, що найбільш конгруентною до сучасних запитів суспільства відносно молодої людини є СЕК. СЕК розглядається як інтегральна здатність, що забезпечує ефективну міжособистісну взаємодію та охоплює когнітивний, емоційний і поведінковий компоненти.

Ми вважаємо, що високий рівень розвитку СЕК може стати запорукою успішної життєдіяльності студентської молоді. Означена компетентність позитивно позначається на особистісній, міжособистісній і навчально-професійній сферах життя студентства, а також дає поштовх до розвитку низки конструктивних особистісних якостей, які здатні ефективно протидіяти можливим психологічним ускладненням, характерним для цього вікового періоду.

Перспективу подальшого дослідження вбачаємо в емпіричній перевірці висунутих у статті теоретичних положень, а саме у визначенні рівня розвитку СЕК студентів.

\section{ЛІТЕРАТУРА:}

1. Андреева И.Н. Предпосылки развития эмоционального интеллекта. Вопросы психологии. 2007. № 5. C. 57-65.

2. Головань М.С. Компетенція і компетентність: досвід теорії, теорія досвіду. Вища освіта України. 2008. № 3. С. 23-30.

3. Изотова Е.И., Никифорова Е.В. Эмоциональная сорера ребенка: Теория и практика : учебное пособие. Москва : Академия, 2004. 288 с.

4. Куницына В.Н. Социальная компетентность и социальный интеллект: структура, функции, взаимо- отношение. Теоретические и прикладные вопросы психологии. 1995. Вып. 1. № 1. С. 48-59.

5. Либина Е.В. Стили реагирования на стресс: психологическая защита или совладание со сложными обстоятельствами? Стиль человека: психологический анализ. Смысл. 1998. С. 190-204.

6. Михайлова Е.С. Социальный интеллект: концепции, модели, диагностика. Санкт-Петербург : Изд-во СПб. ун-та, 2007. 266 с.

7. Семенов В.Ю. Возрастно-половые особенности социоэмоционального интеллекта младших школьников и подростков : дисс. ... канд. психол. наук : 19.00.13. Санкт-Петербург, 2016. 219 с.

8. Тарасова К.С. Типы конкурентного поведения младших школьников с разным уровнем развития социо-эмоциональной компетентности в условиях соревновательных игр : дисс. ... канд. психол. наук : 19.00.13. Москва, 2016. 230 с.

9. Усынина Т.П. Психолого-педагогические условия фрормирования социоэмоциональной компетентности старших школьников, воспитывающихся в интернатных учреждениях : дисс. ... канд. психол. наук : 19.00.07. Самара, 2013. 218 с.

10. Ewart C.K., Jorgensen R.S., Suchday S., Chen E. Measuring Stress Resilience Coping in Vulnerable Youth. The Social Competence Interview. Psychological Assessment. 2002. Vol. 14. P. 339-352.

11. Mayer J.D., Salovey P. What is emotional intelligence? Emotional Development and Emotional Intelligence: Educational Implications. New York, 1997. P. 3-31.

12. Saarni C. The development of emotional competence. Odessa : Guilford Press, 1999. 381 pp.

13. Vernon P.E. Some characteristics of the good judge of personality. Journal of Social Psychology. 1933. Vol. 4. P. 42-57.

14. Weare K. Developing the emotionally literate school. London : Paul Chapman, 2004. 222 p. 